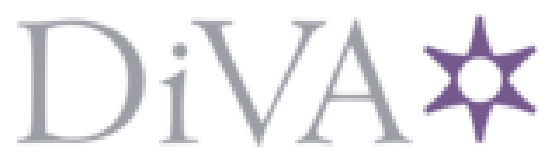

http://www.diva-portal.org

This is the published version of a paper published in Ecological Applications.

Citation for the original published paper (version of record):

Hylander, K., Dynesius, M., Jonsson, B., Nilsson, C. (2005)

Substrate form determines the fate of bryophytes in riparian buffer strips.

Ecological Applications, 15: 674-688

http://dx.doi.org/10.1890/04-0570

Access to the published version may require subscription.

N.B. When citing this work, cite the original published paper.

Permanent link to this version:

http://urn.kb.se/resolve?urn=urn:nbn:se:umu:diva-7640 


\title{
SUBSTRATE FORM DETERMINES THE FATE OF BRYOPHYTES IN RIPARIAN BUFFER STRIPS
}

\author{
Kristoffer Hylander, ${ }^{1,3}$ Mats Dynesius, ${ }^{1}$ Bengt Gunnar Jonsson, ${ }^{2}$ And Christer Nilsson ${ }^{1}$ \\ ${ }^{1}$ Landscape Ecology Group, Department of Ecology and Environmental Science, Uminova Science Park, Umeå University, \\ SE-901 87 Umeå, Sweden \\ ${ }^{2}$ Department of Natural Sciences, Mid Sweden University, SE-851 70 Sundsvall, Sweden
}

\begin{abstract}
Studies on the effectiveness of forest buffer strips left along streams after logging have long overlooked the biota of the buffers themselves, despite their high species richness. We investigated mosses and liverworts (bryophytes), abundant and species-rich groups in boreal forests, before and 2.5 years after logging along 15 small streams. In each site, two $1000-\mathrm{m}^{2}(20 \times 50 \mathrm{~m})$ plots along the stream were inventoried; one plot in an area subjected to clear-cutting, and another in a buffer strip $(10 \mathrm{~m}$ wide on each side of the stream). Ten plots along small streams in forest reserves in the same region were used as references. We found that less than half as many bryophyte species per plot disappeared after logging in the buffer strips compared to the clearcuts. The changes in bryophyte cover and in species composition were smaller in the buffer strips, and the species that were negatively affected in the clearcuts were less affected in the buffer strips. However, there was a significant change in species composition in the buffer strips compared to the references. Substrate form and taxonomic group were important factors in understanding this turnover. Many species growing on substrates with a convex form (e.g., logs, tree bases, and mesic ground) decreased or disappeared, while species on concave substrates were rather unaffected. This held for both mosses and liverworts, although liverworts were generally more sensitive than mosses. The difference in response of assemblages on convex vs. concave substrates makes changes in microclimate due to logging a likely explanation. The species in most need of protection (i.e., the red-listed species) were among the ones with strongest declines in the $20 \mathrm{~m}$ wide buffer strips. In order to function optimally for bryophyte conservation, forests along small streams need to be protected from high windthrow frequency and strong edge effects. Increasing the width of buffer strips at sites with known or potential values (e.g., large amounts of woody debris or boulders) should be considered a better strategy than using narrow buffer strips with a fixed width.
\end{abstract}

Key words: biodiversity; boreal forest; bryophyte; buffer strip; edge effect; liverwort; moss; riparian forest; spatial scale; Sweden.

\section{INTRODUCTION}

Many new management practices to better accommodate the diversity of species and ecological processes are currently implemented in silvicultural systems in boreal and temperate forests both in Europe (Fries et al. 1997, Larsson and Danell 2001) and North America (Kohm and Franklin 1997, Burton et al. 2003). Retention of trees and snags, and prescribed burning are some of the new practices. The objective has been to mimic natural disturbances and thereby promote the maintenance of natural communities (Hansen et al. 1991, Niemelä 1999, Kuuluvainen 2002). Increasing reserve area and modifying management practices on forest land have been emphasized as important components of a sustainable forestry (Larsson and Danell 2001). Whether such a strategy is sufficient to achieve defined goals is, however, largely unknown. It has yet to be demonstrated that the rate of species disappear-

Manuscript received 25 March 2004; revised 24 August 2004; accepted 31 August 2004. Corresponding Editor: D. L. Peterson.

${ }^{3}$ E-mail: kristoffer.hylander@emg.umu.se ance has declined since these modified practices were implemented at a larger scale (Simberloff 1999, Niemelä et al. 2001). Scientific evaluations of the effectiveness of modified forestry have only recently become available (see, e.g., Hazell and Gustafsson 1999, Vanha-Majamaa and Jalonen 2001, Hylander et al. 2002). Such knowledge is greatly needed in developing cost-efficient methods to achieve the biodiversity goals (Niemelä et al. 2001).

Retention of trees along riparian corridors has been suggested as an important management practice (Swanson and Franklin 1992). Retaining such buffer strips have mostly been motivated from a water quality perspective, targeting aquatic biota such as fish and their food (Castelle et al. 1994, Blinn and Kilgore 2001). Recently, their importance for terrestrial biota has also been stressed (Hibbs and Bower 2001, Pearson and Manuwal 2001, Cockle and Richardson 2003), even if the rationale from the perspective of natural disturbance dynamics has been questioned (Macdonald et al. 2004). Although most riparian sites naturally experi- 


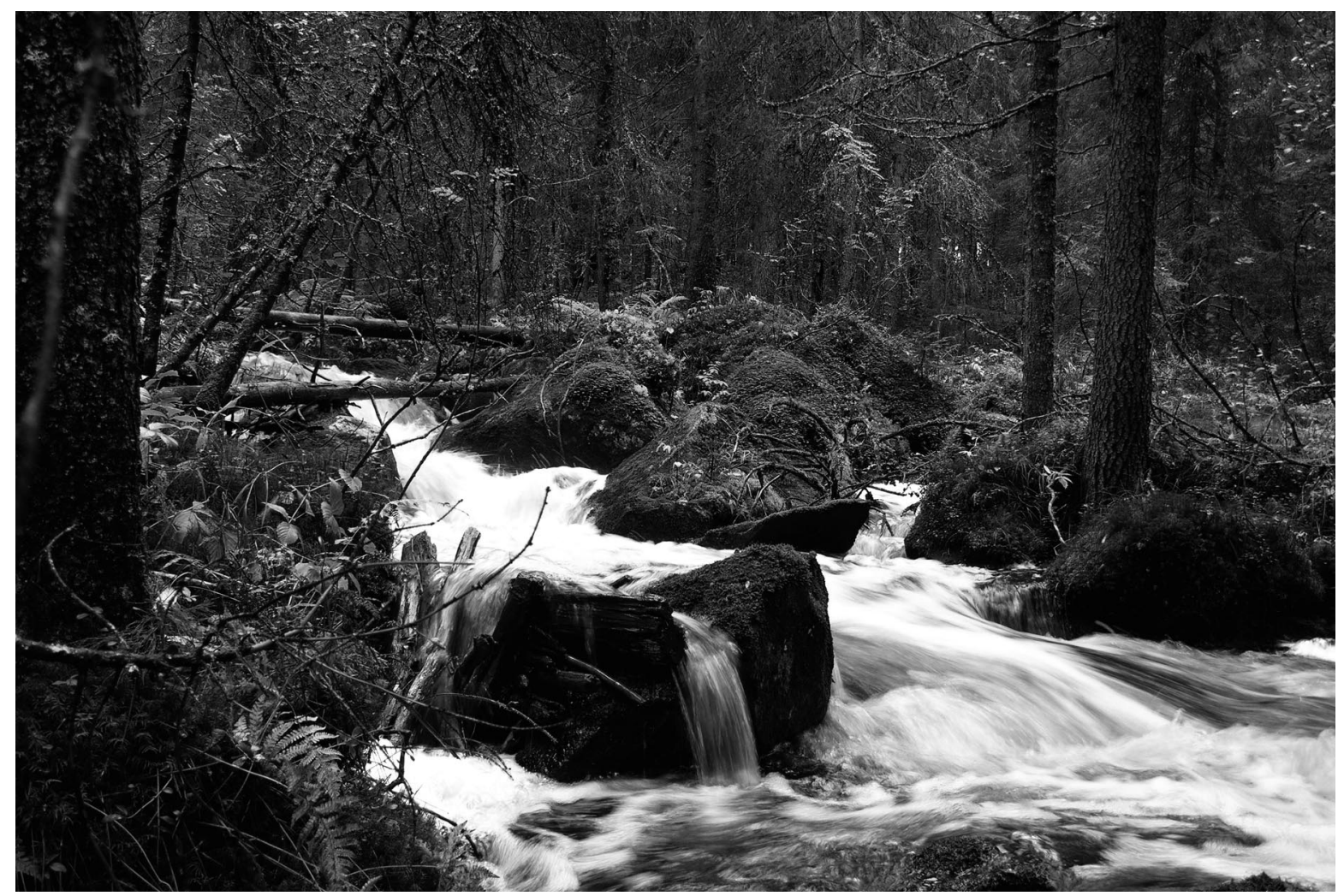

Plate 1. Spruce (Picea abies) forest along a small boreal stream in northern Sweden. Photo: K. Hylander.

ence wildfires with varying frequency (cf. Hörnberg et al. 1998, Granström 2001), leaving buffer strips could still be a good conservation strategy because the total area of late successional stands of high quality (e.g., for species dependent on a moist microclimate and a continuity of woody debris) is small in the landscape. A narrow buffer strip is also probably more similar to a wildfire disturbance along a stream than a clearcut, since natural processes such as production of dead trees and uprootings can continue, shaping microtopographic variation and substrate heterogeneity (cf. Meleason et al. 2003). The focus on riparian forests and buffer strips has mostly considered larger watercourses (Moore and Richardson 2003). Riparian areas of headwater streams, however, deserve more attention, since they are far more common and are critical for water quality further downstream (Gomi et al. 2002).

Mosses and liverworts (bryophytes) play a key role in the ecology of boreal forests. They are important for water balance, erosion control, and nitrogen budget, and offer habitat for many organisms (Esseen et al. 1992, DeLuca et al. 2002, Jönsson 2003). The diversity of bryophytes in the boreal forests often exceeds that of vascular plants at a scale of 0.1 ha, especially in old forests (Berglund and Jonsson 2001). Moist and nutrient-rich sites are species-rich habitats for bryophytes in the boreal forest (Frisvoll and Prest $\varnothing$ 1997, Hörnberg et al. 1998). Forests along small streams constitute such a habitat. We found 75 bryophyte species, on average (range 34-125), in 0.1-ha plots in mature forests along small streams in northern Sweden (see Plate 1; K. Hylander and M. Dynesius, unpublished manuscript). In another study in northern Sweden, 0.1-ha plots of forests along small streams had two to three times more bryophyte species than randomly chosen non-riparian forest plots of the same size (Dynesius 2001). The riparian plots also had three to four times more nationally red-listed species (i.e., nationally threatened or near threatened species according to Gärdenfors 2000) than the non-riparian plots. Bryophytes are poikilohydric, implying that they cannot regulate uptake and loss of water (Proctor 1990). Therefore, their water status more or less follows the humidity of the environment, making them sensitive to an altered microclimate (Proctor 1990, Hylander et al. 2002). Their ecological importance, high riparian diversity, and sensitivity to microclimatic change make bryophytes an obvious choice for evaluating the effectiveness of buffer strips for a group of primarily terrestrial organisms.

Several studies have shown that bryophyte cover declines after clear-cutting (e.g., Hannerz and Hånell 1997, Jalonen and Vanha-Majamaa 2001, Fenton et al. 2003), and a forest fire kills most bryophytes in dry and mesic sites (K. Hylander, personal observation). The response of bryophyte populations to alternative timber-harvesting methods, such as shelterwood log- 

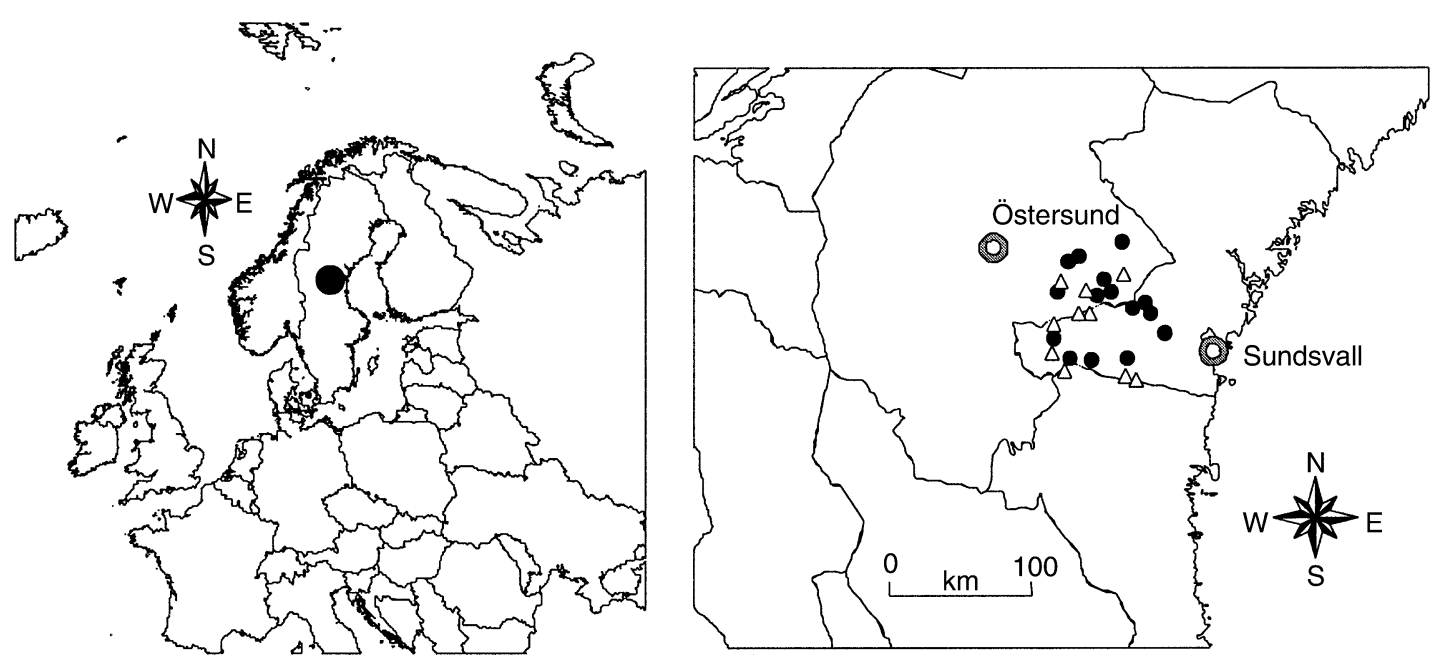

FIG. 1. Location of the study sites in the Swedish counties of Jämtland and Västernorrland. Open triangles denote 10 reference sites of mature forest, and solid circles denote the 15 mature stands that were logged in the experiment.

ging or gap felling, seems to be more equivocal. Hannerz and Hånell (1997) found that most bryophytes retained or increased their cover seven to eight years after shelterwood logging in spruce forests in boreal Sweden. Jalonen and Vanha-Majamaa (2001), on the other hand, found that bryophytes decreased in singletree selection system felling (where $33 \%$ of the stand volume were felled) by the summer after the logging. However, in the same study, they did not find any change in species number or cover from pre-harvest conditions in residual forest patches in spruce forest in southern Finland. Both these studies have low taxonomic resolution and, since the investigated plots were just $0.25-2 \mathrm{~m}^{2}$, only dominant species in the forest floor could be evaluated. No study we know of has evaluated the effects of logging (clear-cutting or any other method) on bryophyte species composition in riparian forest. In a previous experiment, we showed that narrow buffer strips offered unfavorable microclimatic conditions for bryophyte growth, especially when the ground was mesic or moist (as compared to wet; Hylander et al. 2002). It is, however, unclear how this finding relates to the survival of populations. A reduced growth does not necessarily cause local extinction of populations.

In this study, we experimentally evaluated the effectiveness of buffer strips in moderating changes in the moss and liverwort communities after clear-cutting of the surrounding forest. We also asked whether bryophyte assemblages on different substrates and of different macrohabitat association, and red-listed bryophytes differed in their response to the changed environmental conditions. We did this by studying large plots $\left(200-1000 \mathrm{~m}^{2}\right)$ in mature stands with intersecting streams before and 2.5 years after logging. In this way, the many infrequent species were also included.

\section{Methods \\ Study area}

The study was conducted in the middle boreal zone described by Ahti et al. (1968) in the counties of Västernorrland and Jämtland in central Sweden at $62^{\circ} 40^{\prime}$ $\mathrm{N}$ and $16^{\circ} 05^{\prime} \mathrm{E}$ (midpoint of the area; Fig. 1). The area has been subjected to repeated Pleistocene glaciations and most of the till is derived from rather acidic granitic and metamorphic rocks (Fredén 1994). There is, however, some influence from, e.g., diabase raising the soil and water $\mathrm{pH}$ somewhat in the area. The highest postglacial coastline is situated at $\sim 240 \mathrm{~m}$ above sea level (asl), and most of the study sites were located above it (225-430 $\mathrm{m}$ asl). The yearly precipitation is $\sim 700$ $\mathrm{mm}$, and the mean temperature for January is $-10^{\circ} \mathrm{C}$ and for July $+14^{\circ} \mathrm{C}$ (Raab and Vedin 1995). The mature forest is dominated by conifer trees (Scots pine Pinus sylvestris L. and Norway spruce Picea abies L. Karst.), with scattered birches (Betula pubescens Ehrh. and B. pendula Roth) and aspen (Populus tremula L.). Along lakeshores and riverbanks, gray alder (Alnus incana (L.) Moench) and birch are common. The landscape has been subject to industrialized logging for $\sim 150$ years, and clear-cutting has been the dominating logging practice for the last 50 years (Nilsson 1990). The bryophyte flora of the forests along small streams in this area is comparatively species rich compared to similar sites in other parts of northern Sweden. The rich flora is caused by a high abundance of boulders, relatively high $\mathrm{pH}$ in soil and water, and a relatively good supply of coarse woody debris, which creates a heterogeneous habitat (K. Hylander and M. Dynesius, unpublished manuscript).

\section{Study design}

In collaboration with the forest company SCA (Svenska Cellulosa Aktiebolaget), we selected 15 mature for- 
a
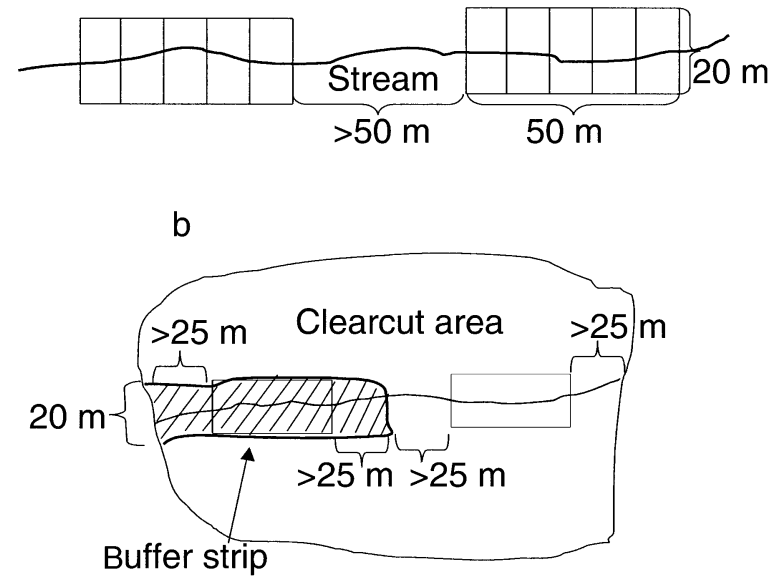

FIG. 2. Experimental setup for the 15 logged sites. (a) Two plots were placed along the stream before logging. Each plot was divided into five segments of $10 \times 20 \mathrm{~m}$. (b) A buffer strip (hatched area) was left along one of the plots when the stand was clear-cut. The minimum distances between the plots, between the plots and the stand edge, and between the buffer strip plot and the end of the buffer strip are indicated.

est stands with intersecting small (first- to secondorder) streams scheduled for clear-cutting. In each stand, we established two $1000-\mathrm{m}^{2}$ plots along the stream at a minimum distance of $50 \mathrm{~m}$ from each other (Fig. 2a). The $1000-\mathrm{m}^{2}$ plots $(20 \times 50 \mathrm{~m})$ were placed with the stream crossing the middle of the short sides and with the stream channel entirely within the plot. During the summer of 1998 (21 July-7 September), we inventoried the plots, and in the winter of 1998/1999 the forests were logged. All trees were cut in one of the plots and in the other a buffer strip of $10 \mathrm{~m}$ was left on both sides of the stream (Fig. 2b). We then reinventoried the plots 8 July-9 August 2001, the third summer after the logging. In addition to these 15 sites, 10 reference stands of mature forest along small streams in nature reserves were selected. Along these streams, randomly located reference plots were surveyed in the same way and during the same periods as the other plots. The year after the inventory (1999) was rather normal regarding summer (June to August) temperature and precipitation, but the next summer (2000) was $0.6^{\circ} \mathrm{C}$ cooler and much wetter (more than the double amount of rain fell in June to August) compared to an average year in a 30-year period (Torpshammar weather station; Anonymous 1999, 2000). The beginning of the summer of 2001 was rather dry $(27 \mathrm{~mm}$ compared to on average $44 \mathrm{~mm}$ in June), but July was warm and wet (92 $\mathrm{mm}$ compared to the average 63 mm; Anonymous 2001).

\section{Environmental variables}

Before logging (1998) we estimated and measured a number of variables in all plots, but after logging
(2001) we gathered environmental data only in the clearcuts and buffer strips. In 1998 we estimated by eye the proportions of wet, moist, and mesic ground according to definitions in Hägglund and Lundmark (1981) in the $1000-\mathrm{m}^{2}$ plot. We combined these values into a moisture index through the following algorithm: (percentage of mesic ground $\times 1$ ) + (percentage of moist ground $\times 2)+($ percentage of wet ground $\times 3$ ). This index ranges from 100 to 300, with 300 being wettest. We measured the slope of the stream along the $50-\mathrm{m}$ stretch and the lateral slopes from the center of the stream on both sides to points $10 \mathrm{~m}$ perpendicular to the channel at four places. We estimated the ground cover of exposed boulders (i.e., not covered by ground vegetation) in 1998 and exposed mineral soil in both 1998 (mostly mounds and pits of uprootings) and 2001 (machine tracks, uprootings, and deposited sediment packs). In the clear-cut areas and buffer strips, we also estimated the cover of slash in 2001. In both 1998 and 2001, we measured the basal area of living Scots pine, Norway spruce, and deciduous trees using a relascope at two points along the mid line of the plot at 12.5 and $37.5 \mathrm{~m}$ from one short side and calculated a mean value. The proportion of measured basal area after the cutting in 1998/1999 and subsequent wind felling could then be calculated (this is not a totally accurate measure of how the basal area in the plot has changed because the method [relascope] allows a few large trees outside the plot to be included). After logging we also counted all the new windthrows, new stumps, and standing living trees (all species, diameter $>10 \mathrm{~cm}$ ) within the 1000$\mathrm{m}^{2}$ buffer strip plots. The percent cover of overstory and of vascular plant understory were each estimated by eye in both 1998 and 2001 to allow calculation of change in these variables.

\section{Bryophyte inventory}

Each of the 40 plots was divided into five segments $\left(10 \times 20 \mathrm{~m}, 200 \mathrm{~m}^{2}\right.$; Fig. $\left.2 \mathrm{a}\right)$, and the presence of bryophyte species was recorded for every segment both in 1998 and 2001. During re-inventory, species lists from the previous inventory were used. Patches of species that were nationally red-listed at the time of the first inventory (Aronsson et al. 1995) were mapped in 1998 and 2001. This procedure was used to increase the reliability of the data for the infrequent red-listed species. Only rarely was more than one patch of a redlisted species found in a segment. Therefore, we report presence/absence data on the segment level $\left(200 \mathrm{~m}^{2}\right)$ and not data on the number of patches. This made it easier to compare red-listed species with other species, and to include species recently added to the red-list (Gärdenfors 2000). The first author made the bryophyte inventories both times.

We collected many small bryophyte samples to ensure correct identification of species, but the following combinations of species were treated as one taxon each: Chiloscyphus pallescens and C. polyanthos, Lophozia 
gillmanii and L. bantriensis, L. silvicola and L. ventricosa, Pellia neesiana and P. epiphylla, Scapania scandica and $S$. mucronata, Atrichum undulatum and A. tenellum, Philonotis fontana and P. tomentella, Plagiothecium laetum and $P$. curvifolium, and Rhizomnium magnifolium and $R$. pseudopunctatum. The nomenclature follows Söderström and Hedenäs (1998), except for Lophozia ciliata, which was recently described (Söderström et al. 2000). Voucher specimens are deposited at the herbaria of the Department of Ecology and Environmental Science in Umeå (UME) and the Swedish Museum of Natural History in Stockholm (S), Sweden.

We analyzed different subgroups of species according to main substrate association in the plots and main macrohabitat in the landscape. Each species was assigned to one substrate group based on data collected during the first inventory. A species occurring on two or more substrates was assigned to the substrate on which it was recorded most times (for details see K. Hylander and M. Dynesius, unpublished manuscript). The classification of main macrohabitat group was based on personal experience and literature (for details see K. Hylander and M. Dynesius, unpublished manuscript). Most of the 14 substrate categories were lumped into two groups: concave and convex substrates. Moist ground, wet ground, stream channel margin, and crevices, which all are characterized by being close to the ground water table, were classified as concave substrates. The convex substrates are boulders on land, trees and tree bases, mesic ground, stumps and logs, which all are elevated from the ground water table. The substrate categories "exposed mineral soil," "dung and carcass," and "stream boulders" representing, on average, $13 \%$ of the species in a $1000-\mathrm{m}^{2}$ plot and $9 \%$ in a $200-\mathrm{m}^{2}$ plot were not included in the convex/concave classification. A boulder in a stream is, of course, a convex substrate, but since it is strongly influenced by stream water, it was not included in the convex group. The four macrohabitat groups are "forest species," "open-mire species," "rocky-outcrop species," and "road bank and riverbank species." The last category includes species on more-or-less exposed soil in light environments.

Most contemporary researchers consider bryophytes to be a paraphylethic group (Goffinet 2000). It is therefore appropriate to consider mosses and liverworts separately. Because of the similarity in physiology, life cycle, and substrate affinity (Schofield 1985), it is, however, in many cases practical to lump the groups together. In this paper we treat mosses and liverworts separately in some analyses, but together as bryophytes in analyses of the different substrate or macrohabitat groups.

\section{Statistical analyses}

We analyzed the difference between treatments regarding change in bryophyte species composition (mosses and liverworts pooled) before and after the cutting using multi-response permutation procedures (MRPP) and blocked multi-response permutation procedures (MRBP) in the statistical package PC-ORD (McCune and Mefford 1999). MRPP and MRBP are nonparametric statistical methods for testing the hypothesis of no difference in for example species composition between two or more a priori groups (see, e.g., Zimmerman et al. 1985). Two species-by-site matrices were compiled: one with the buffer strip and reference sites and one with the buffer strip and clear-cut sites. As the response variable, the change in frequency for each species between the pre-logging and post-logging inventory was used. If, for example, a species had disappeared from two out of four segments, the value -2 was put in that cell in the matrix. The difference between change in species composition between buffer strips and references was tested with MRPP with Euclidean distance used as distance measure and $n / \operatorname{sum}(n)$ as weighting factor. The distance matrix (species-bysites) was not rank-transformed. The difference between the change in species composition in the buffer strips and the clearcuts was tested with MRBP, since this analysis was paired. Sites were used as blocks, and the median for each block was aligned. In this analysis, Euclidian distance was again used as the distance measure.

For every species in the clearcuts and buffer strips, we calculated the mean change in number of $200-\mathrm{m}^{2}$ segments where it was found between 1998 and 2001. The mean segment frequency change was calculated only from the $1000-\mathrm{m}^{2}$ plots where the species was present in at least one of the years. The values can range from -5 to +5 , with 0 indicating no change in segment frequency for that species. By plotting the changes in frequency in clearcuts vs. buffer strips for the species occurring in both treatments, we could analyze the correlation in effects between treatments.

The difference in number of species per plot (or relative change in number of species per plot) between clearcuts and buffer strips was analyzed using Wilcoxon's signed-rank test. The difference between buffer strips (as well as clearcuts) and the references was analyzed with a Mann-Whitney $U$ test, since those data were not paired. Nonparametric tests were chosen because of non-normality in many cases, and small samples of discrete data in some. These analyses were made using the statistical package SPSS (Norušis 1999). Since buffer strips were the main focus, we corrected the level of $\alpha$ for those analyses (i.e., buffer strip vs. clearcut and buffer strip vs. reference) and report significant differences for single comparisons when $P<$ 0.025 (i.e., 0.05/2). (For clarity in the figures, the difference between clearcuts and references was also indicated at the same level of $\alpha$, although not reported elsewhere or discussed.)

The results from the references should be viewed as a baseline to which the change in clearcuts and buffer 
TABLE 1. Mean and range of environmental variables in the clearcut plots, buffer strip plots, and reference plots in forests along small streams prior to logging (1998), and the change after logging (2001) at the study sites in central Sweden.

\begin{tabular}{|c|c|c|c|c|c|c|}
\hline \multirow[b]{2}{*}{ Variable } & \multicolumn{2}{|c|}{ Clearcuts } & \multicolumn{2}{|c|}{ Buffer strips } & \multicolumn{2}{|c|}{ References } \\
\hline & Mean & Range & Mean & Range & Mean & Range \\
\hline \multicolumn{7}{|l|}{ Conditions before logging (1998) } \\
\hline Total basal area $\left(\mathrm{m}^{2} / \mathrm{ha}\right)$ & 34.8 & $18-45$ & 36.1 & $18.5-56.5$ & 26.4 & $12.5-50$ \\
\hline Spruce basal area $\left(\mathrm{m}^{2} / \mathrm{ha}\right)$ & 20.6 & $1-40.5$ & 22.9 & $1-49$ & 17.4 & $0.5-39$ \\
\hline Pine basal area $\left(\mathrm{m}^{2} / \mathrm{ha}\right)$ & 9.2 & $0-27.5$ & 8.0 & $0-30$ & 4.4 & $0-16$ \\
\hline Deciduous basal area (m²/ha) & 5.0 & $0-27.5$ & 5.2 & $0.5-20.5$ & 4.6 & $0.5-10.5$ \\
\hline Tree cover $(\%)$ & 68 & $50-90$ & 65 & $50-90$ & 60 & $30-90$ \\
\hline Understory cover (\%) & 81 & $70-90$ & 80 & $40-90$ & 70 & $50-90$ \\
\hline Bryophyte cover (\%) & 85 & $70-100$ & 82 & $40-100$ & 80 & $30-95$ \\
\hline Moisture index $\dagger$ & 191 & $120-240$ & 195 & $130-260$ & 180 & $135-250$ \\
\hline Cover of boulder (\%) & 2 & $0-5$ & 1.3 & $0-5$ & 3.2 & $0-14$ \\
\hline Cover of mineral soil (\%) & 0.3 & $0-1.4$ & 0.6 & $0-3.6$ & 0.1 & $0-0.5$ \\
\hline Stream slope $(\%)$ & 4.3 & $0.4-7.2$ & 4.4 & $2.3-6.8$ & 3.4 & $0.45-6.5$ \\
\hline Lateral slope $(\%)$ & 10 & $4-34$ & 11.1 & $4.1-45.2$ & 17 & $5.2-72$ \\
\hline \multicolumn{7}{|l|}{ Changes due to logging (2001) } \\
\hline Cover of slash $(\%)$ & 7.5 & $1-15$ & 0.7 & $0-2.8$ & $\ldots$ & $\ldots$ \\
\hline Tree cover change $(\%) \ddagger$ & -67.5 & -90 to -50 & -20 & $-75-10$ & $\ldots$ & $\ldots$ \\
\hline Understory cover change $(\%) \ddagger$ & -4.2 & $-20-5$ & -5.5 & $-30-35$ & $\ldots$ & $\ldots$ \\
\hline Bryophyte cover change $(\%) \neq$ & -57.7 & -90 to -20 & -18 & $-80-0$ & $\ldots$ & $\ldots$ \\
\hline Proportion left of basal area $(\%)$ & 0 & 0 & 60 & $30-90$ & $\ldots$ & $\ldots$ \\
\hline Proportion of trees felled by wind (\%) & $\ldots$ & $\ldots$ & 24 & $0-68$ & $\ldots$ & $\ldots$ \\
\hline Change in mineral soil cover $(\%) \ddagger$ & 1 & $-1.2-10$ & 3.4 & $-3-14.8$ & $\ldots$ & $\ldots$ \\
\hline
\end{tabular}

$\dagger$ See Methods section; higher values denote wetter ground.

$\mp$ Expressed as change of percentage points, e.g., if the cover was $80 \%$ and now is $20 \%$, it has decreased by 60 percentage points. It is not calculated as $60 / 80$, i.e., $75 \%$ decrease.

strips should be compared to and not as a treatment, where the response should be evaluated and explained. This is important to recognize, since we have worked with large plots, where, in addition to species turnover, the second inventory was more effective as data from the first inventory were available. The second time we made the inventory, we found each species in on average 0.22 more $200-\mathrm{m}^{2}$ segments per $1000-\mathrm{m}^{2}$ plot in the references. Also, the number of species found the second time was higher in nine out of 10 reference plots $\left(1000 \mathrm{~m}^{2}\right)$. There is no reason to believe that there should have been a real increase in species numbers in the reference plots over these three years. The reference baseline to which the result in the treatment should be compared, in many cases, thus showed a net increase in number of species between the years (see, e.g., $R e$ sults: Red-listed species).

\section{RESUlts}

\section{Environmental variables}

The mean and range were similar for all environmental variables in clearcuts, buffer strips, and references prior to logging (Table 1). After logging, the clearcuts were more different compared to pre-logging conditions than the buffer strips regarding tree cover variables (basal area, tree cover) and logging slash cover (7.5\% vs. $0.7 \%, P=0.001$, Wilcoxon's signed-rank test). Erosion of the stream channel margins or sedimentation due to flooding at the clearcuts was not common. Instead, the change in amount of exposed mineral soil was higher in the buffer strips due to new wind- throws $(+1 \%$ vs. $+3.4 \%, P=0.05$, Mann-Whitney $U$ test of percentage points). The proportion of the number of trees that were windthrown after logging in buffer strip plots varied between $0-68 \%$, with a mean of $24 \%$ (felled mostly during the first year; Table 1). The tree cover decreased by an average of 20 percentage points. There was a large variation in environmental variables among the sites prior to logging (Table 1). As an example, the basal area in the buffer strip plots varied between $18.5 \mathrm{~m}^{2} /$ ha and $56.5 \mathrm{~m}^{2} /$ ha (Table 1 ). Spruce was the dominating tree species, but a few sites had high basal areas of pine or deciduous trees (birch and alder) as well. There was also variation in ground moisture, with some sites being rather wet and others being dominated by mesic ground (Table 1).

\section{Bryophyte cover}

The average cover of bryophytes decreased from $81.7 \%$ to $63.7 \%$ (range: -80 percentage points to no change) in the buffer strips and from $84.7 \%$ to $27.0 \%$ in the clearcuts (range: -90 to -20 percentage points) (the reference plots were not evaluated in this respect). These changes were statistically significant $(P=$ 0.0006 and $P=0.0030$, respectively, Wilcoxon's signed-rank test), as was the difference in response between clearcuts and buffer strips $(P=0.0006$, Wilcoxon's signed-rank test).

\section{Species numbers before logging}

A total of 118 bryophyte species were found in the 15 buffer strip plots prior to logging. The total number 
TABLE 2. Number of bryophyte species in forests along small streams prior to logging, grouped according to main substrate association (see Methods for the basis of the division of species), main macrohabitat, and taxonomic group (mosses vs. liverworts).

\begin{tabular}{lccc}
\hline \hline & \multicolumn{2}{c}{$\begin{array}{c}\text { Average no. } \\
\text { species }\end{array}$} & $\begin{array}{c}\text { Total no. } \\
\text { species }\end{array}$ \\
\cline { 2 - 3 } \multicolumn{1}{c}{ Group } & $\begin{array}{c}1000 \\
\mathrm{~m}^{2}\end{array}$ & $\begin{array}{c}200 \\
\mathrm{~m}^{2}\end{array}$ & $\begin{array}{c}\text { in 15 buffer } \\
\text { strip plots }\end{array}$ \\
\hline Convex-substrate species $\dagger$ & 29 & 19 & 62 \\
Concave-substrate species $\neq$ & 41 & 26 & 93 \\
Forest species & 54 & 37 & 88 \\
Open-mire species & 8.2 & 4.2 & 33 \\
Rocky-outcrop species & 7.1 & 3.7 & 37 \\
Road- and riverbank species & 9.8 & 5.7 & 23 \\
Mosses & 49 & 33 & 119 \\
Liverworts & 30 & 18 & 62 \\
Red-listed species & 2.4 & 0.9 & 9
\end{tabular}

Notes: Mean values for $1000-\mathrm{m}^{2}$ plots and $200-\mathrm{m}^{2}$ plots before cutting are given (using all plots, $N=40$ ), as well as the total number of species encountered in the 15 plots that were left as buffer strips (pre-logging).

$\uparrow$ Convex substrates include logs, stumps, tree bases, mesic ground, epiphytes on deciduous trees, and boulders on land.

\$Concave substrates include moist ground, wet ground, stream channel margin, and crevices.

of species on concave substrates as well as the mean number per plot was higher than for species on convex substrates (ratio 1.4-1.5, mean of all 40 plots; Table 2 ). On average, $68 \%$ of the species in a plot were forest species (Table 2). One-third of the total number of bryophyte species in all buffer strips were liverworts, and two-thirds were mosses (Table 2). On average, 49 moss species and 30 liverwort species were found in a $1000-m^{2}$ plot (Table 2).

\section{Changes in species composition}

The change in species composition in the buffer strips between the pre- and post-logging inventories differed significantly $(P<0.001)$ from the change in the references as revealed by the MRPP analysis. The mean change in frequency of the species in the references did not correlate significantly with the mean change in frequency for the same species in the buffer strips $(r=0.06, P>0.05)$, indicating no common change in overall species composition over the inventory years. Between the buffer strip plots and the clearcut plots, the MRBP analysis also showed that the difference in the change in species composition was statistically significant $(P<0.001)$. However, in this case, the mean change in frequency of the bryophyte species in the buffer strips was significantly positively correlated $(r=0.74, P<0.001)$ with the mean change in frequency of the same species in the clearcuts (Fig. 3). This shows that the direction of response (positive or negative to logging) for the species was mostly similar in the buffer strips and the clearcuts. However, the nominal values were higher in the clearcuts for both decreasing and increasing species, resulting in a slope

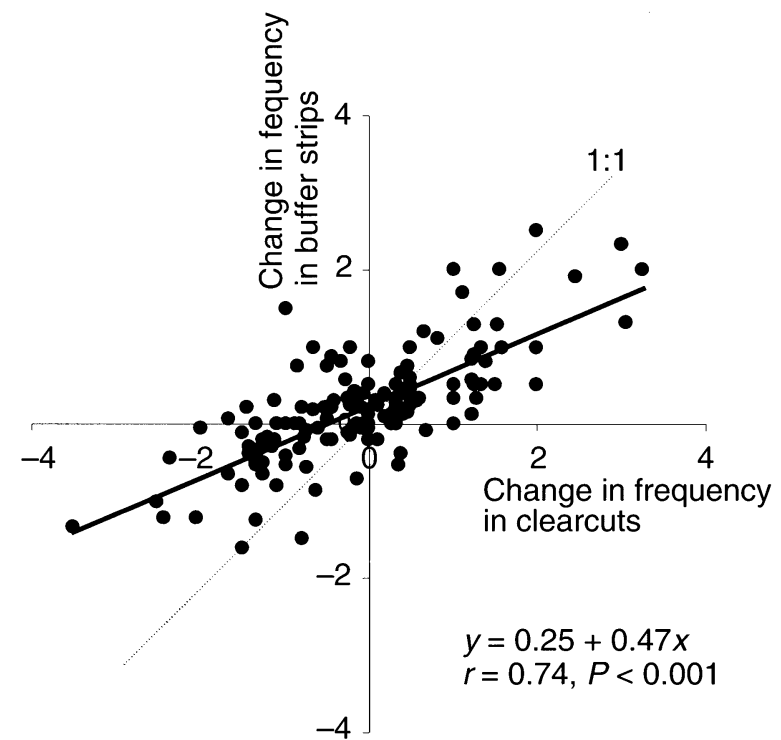

FIG. 3. Change in segment frequency after logging for bryophyte species in clearcut plots vs. the change in buffer strip plots for the same species. The segment frequency is the mean number of $200-\mathrm{m}^{2}$ plots occupied by the species per $1000-\mathrm{m}^{2}$ plot. The markers represent the 141 species that were at least present in both two clearcut and two buffer strip plots (either before or after the logging). Hence, the 43 most infrequent species were excluded. Values along the axes represent the response of the species to logging, where a negative value denotes decreases in segment frequency of the species and a positive value denotes increasing segment frequency. The slope of the regression line $(y=0.25+0.41 x)$ differs significantly $(P<0.05)$ from the slope of the $1: 1$ line, indicating that the species generally were more affected (positively or negatively) at the clearcuts than in the buffer strips. Pearson's correlation coefficient $r=0.74, P<0.0001$.

of the regression significantly $(P<0.001)$ different from the 1 to 1 line (Fig. 3).

\section{Substrate associations}

Species growing on different substrates responded differently to logging. The change of bryophyte species on convex substrates was totally dominated by lost species (Fig. 4a, b). The proportion of lost species in buffer strips was intermediate to clearcuts and references, and differed significantly $(P<0.0030)$ from both of them at both plot sizes (Fig. 4a, b). At the 200- $\mathrm{m}^{2}$ scale, the number of lost species on convex substrates per plot was nine percentage points fewer than in the clearcuts, representing almost two species. Within the convex group, species growing on woody debris and mesic soil were the most negatively affected (see Appendix). For species on concave substrates, both the numbers of new and of lost species were similar in the treatments compared to the references in the $1000-\mathrm{m}^{2}$ plots (Fig. 4c). At the smaller scale, there were both more new and lost species in buffer strips and clearcuts compared to the references (significant only in clearcuts; Fig. 4d). 

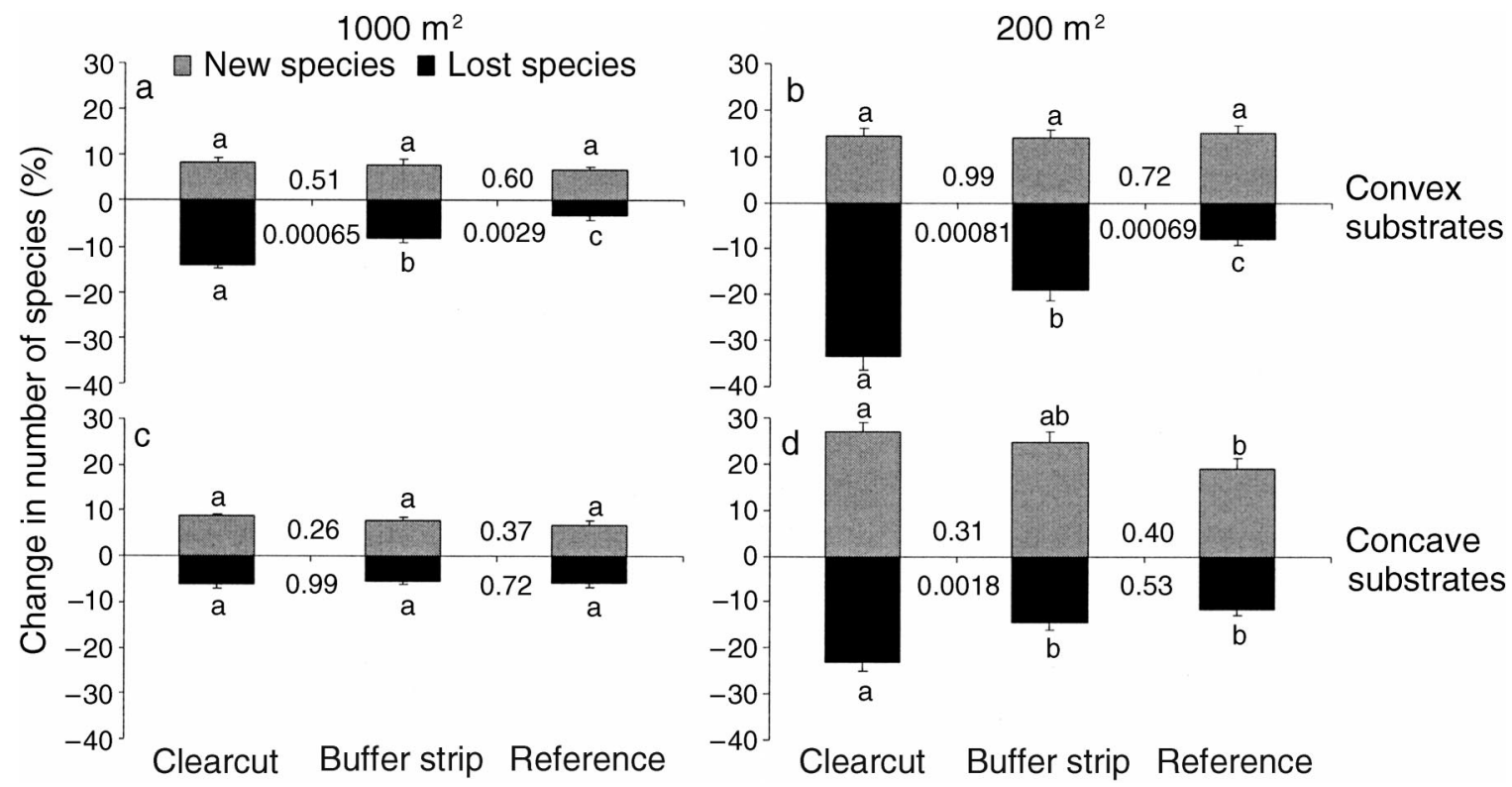

FIG. 4. Turnover of bryophyte species grouped according to an association with convex or concave substrates in clearcuts $(N=15)$, buffer strips $(N=15)$, and reference sites $(N=10)$ between 1998 (pre-logging) and 2001 (post-logging) at two different plot sizes: (a) species on convex substrates in 1000- $\mathrm{m}^{2}$ plots, (b) species on convex substrates in $200-\mathrm{m}^{2}$ plots, (c) species on concave substrates in $1000-\mathrm{m}^{2}$ plots, and (d) species on concave substrates in $200-\mathrm{m}^{2}$ plots (error bars denote +1 $\mathrm{SE})$. The letters denote significant differences $(P<0.025)$ between treatments, evaluated using Wilcoxon's signed-rank test (paired buffer strips vs. clearcuts) and Mann-Whitney $U$ test (comparisons with the references). $P$ values are given for the comparisons that include buffer strips.

\section{Macrohabitat association}

Lost species contributed all extra (compared to references) turnover of forest species in buffer strips and clearcuts (Fig. 5a). The numbers of new species in clearcuts and buffer strips were even fewer than in the references, indicating that the actual decrease was even larger. The decrease in number of forest species was, however, significantly lower in buffer strips compared to clearcuts (six species less at both plot sizes; Fig. 5a for $200 \mathrm{~m}^{2}$ ).

New species with their main habitat on road- and riverbanks were recruited in buffer strips and clearcuts (Fig. 5b). The number of new species in buffer strips compared to references was nominally low (1.9 species), but since this assemblage was species poor (Table 2 ) it corresponds to an increase of $33 \%$. Most of this increase consisted of moss species growing on exposed mineral soil (for details see Appendix). The turnover after logging of open-mire species as well as of species with their main habitat on rocky outcrops differed little between buffer strips and references regarding both new species and lost species (Fig. 5c, d).

\section{Taxonomic groups}

For both mosses and liverworts, the turnover in the buffer strips was intermediate compared to the turnover in the clearcuts and references (Fig. 6a, b). The buffer strips were more similar to the clearcuts in terms of number of new moss species and to the references in terms of number of moss species only found before logging (Fig. 6a, b). Excess turnover (the turnover that exceeded the turnover in the references) of mosses in buffer strips was dominated by new species in both the $1000-\mathrm{m}^{2}$ and $200-\mathrm{m}^{2}$ plots. In terms of the number of lost moss species per plot, the buffer strips were effective with no significant difference from the references.

In contrast, lost species contributed all extra turnover for liverworts in buffer strips and clearcuts compared to references (Fig. 6c, d). In the buffer strips, 4.3 liverwort species (corresponding to $25 \%$ ), on average, were absent after logging in the $200-\mathrm{m}^{2}$ plots. This is significantly $(P<0.001)$ fewer than in the clearcuts $(7.7 ; 43 \%)$, and significantly $(P<0.001)$ more than in the references $(2.0 ; 10 \%)$. At the $1000-\mathrm{m}^{2}$ scale, the pattern was similar but values were lower (Fig. 6c). The number of lost species in the buffer strips was about half the number that disappeared in the clearcuts.

There was a higher proportion of liverworts on convex than on concave substrates in the buffer strips (prelogging values: $47 \%$ of the 62 species on convex substrates vs. $29 \%$ of the 93 species on concave substrates). However, substrate form (convex vs. concave) was an important component for the outcome of logging for both mosses and liverworts (Fig. 7). The mean change in segment frequency (omitting species with only one record before and/or after the logging) of species on convex substrates in the buffer strips dif- 

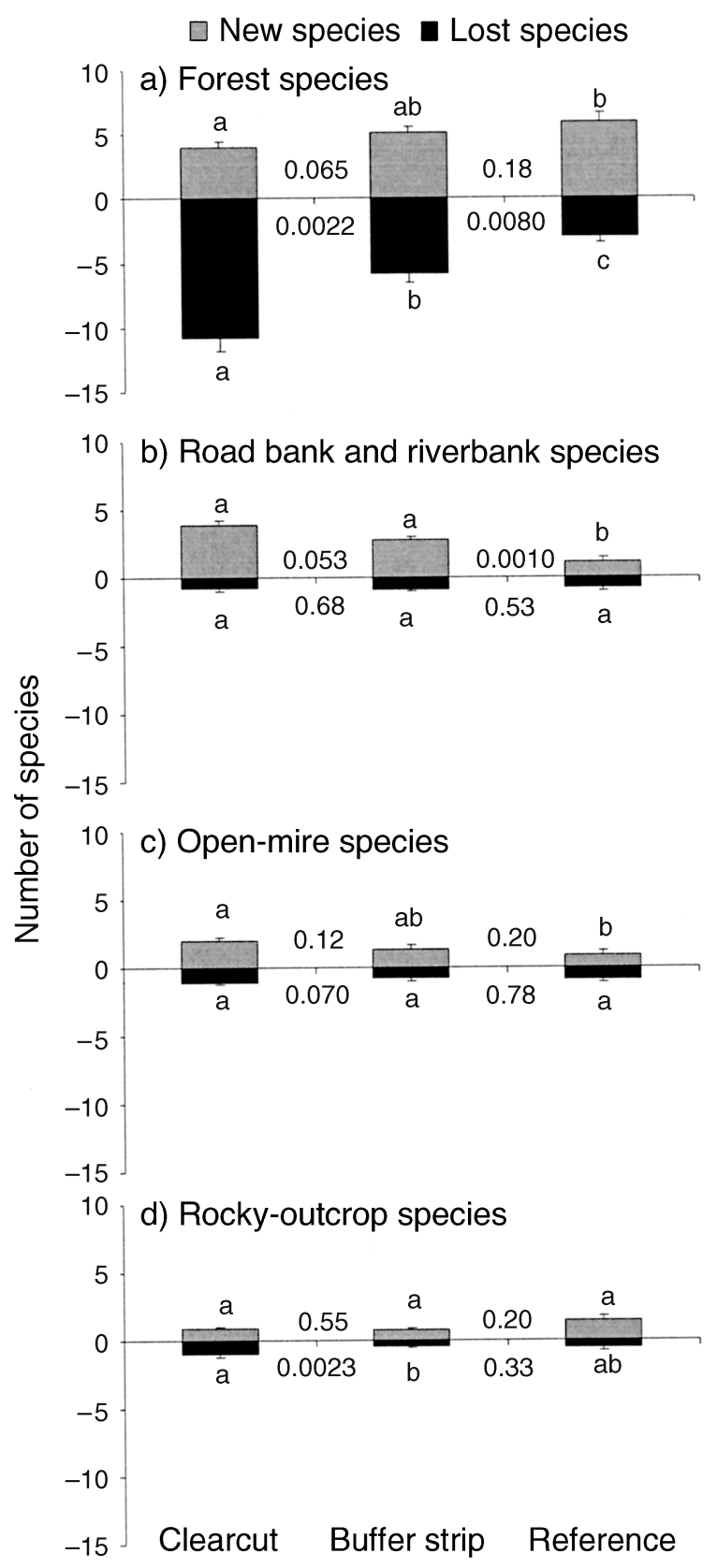

FIG. 5. Turnover of bryophyte species in $200-\mathrm{m}^{2}$ plots grouped according to their main macrohabitat in the landscape in clearcuts $(N=15)$, buffer strips $(N=15)$, and reference sites $(N=10)$ between 1998 (pre-logging) and 2001 (postlogging): (a) forest species, (b) road bank and riverbank species, (c) open-mire species, and (d) rocky-outcrop species (error bars denote $+1 \mathrm{SE}$ ). Species from all groups were present in all plots. The letters denote significant differences $(P$ $<0.025$ ) between treatments, evaluated using Wilcoxon's signed-rank test (paired buffer strips vs. clearcuts) and MannWhitney $U$ test (comparisons with the references). $P$ values are given for the comparisons that include buffer strips. fered significantly from the values of species on concave substrates for both liverworts $(P=0.0040$, MannWhitney $U$ test $)$ and mosses $(P=0.0089)$. The negative response to logging (measured as mean change in segment frequency) was, however, significantly stronger for liverworts than for mosses. On convex substrates in buffer strips, $81 \%$ of the liverworts were negatively affected compared to $32 \%$ of the mosses $(P=0.0022$, Mann-Whitney $U$ test on difference in mean change in frequency between moss species and liverwort species). On concave substrates, the figures were $44 \%$ and $16 \%$ for liverworts and mosses, respectively $(P=$ 0.0017 , Mann-Whitney $U$ test on difference in mean change in frequency).

\section{Red-listed species}

The number of nationally red-listed species found in a $1000-\mathrm{m}^{2}$ plot prior to the logging varied between 0 and $5($ mean $=2.1)$ in the treated plots and between 0 and $9($ mean $=3.3)$ in the reference plots. Before logging (1998), red-listed species were absent from only four clear-cut sites, two buffer strip sites, and two reference sites. On average, the number of red-listed species in the buffer strips decreased $30 \%$ in the $1000-\mathrm{m}^{2}$ plots and $42 \%$ in the $200-\mathrm{m}^{2}$ plots, which should be compared to the increase of $29 \%$ and $56 \%$ found in the reference plots (Fig. 8). The differences between buffer strips and references and buffer strips and clearcuts were significant $(P<0.025)$ at both plot sizes (Fig. 8 ). The four most frequent red-listed species (Anastrophyllum hellerianum, Calypogeia suecica, Lophozia ascendens, L. longiflora) were among the most negatively affected by logging with marked declines in both clearcuts and buffer strips (see Appendix). Since a record in one 200- $\mathrm{m}^{2}$ segment corresponds to approximately one colony or patch of a red-listed species (see Methods section) we could sum all 200- $\mathrm{m}^{2}$ plot records to get an approximation of the number of patches in the total data set. After the logging, we found half as many $200-\mathrm{m}^{2}$ plot records of red-listed species as before the logging (32 vs. 64) in the buffer strips. The real disappearance was higher as a number of colonies were not found the first time. The change in the buffer strips was, however, much smaller than in the clearcuts, where almost $90 \%$ of the colonies (i.e., 200- $\mathrm{m}^{2}$ plot records) had disappeared.

\section{DISCUSSION}

We asked whether buffer strips (of $10 \mathrm{~m}$ width on each side of a stream) are effective in protecting the rich bryophyte flora in forests along small streams when the surrounding forest is clear-cut. The answer is both yes and no. The bryophyte cover was more-orless intact in the buffer strips, and the number of species that had disappeared after logging was distinctly reduced compared to the situation in the clearcuts (Figs. 4-6), indicating an overall conserving effect of the buffer strips. It is thus likely that buffer strip retention 

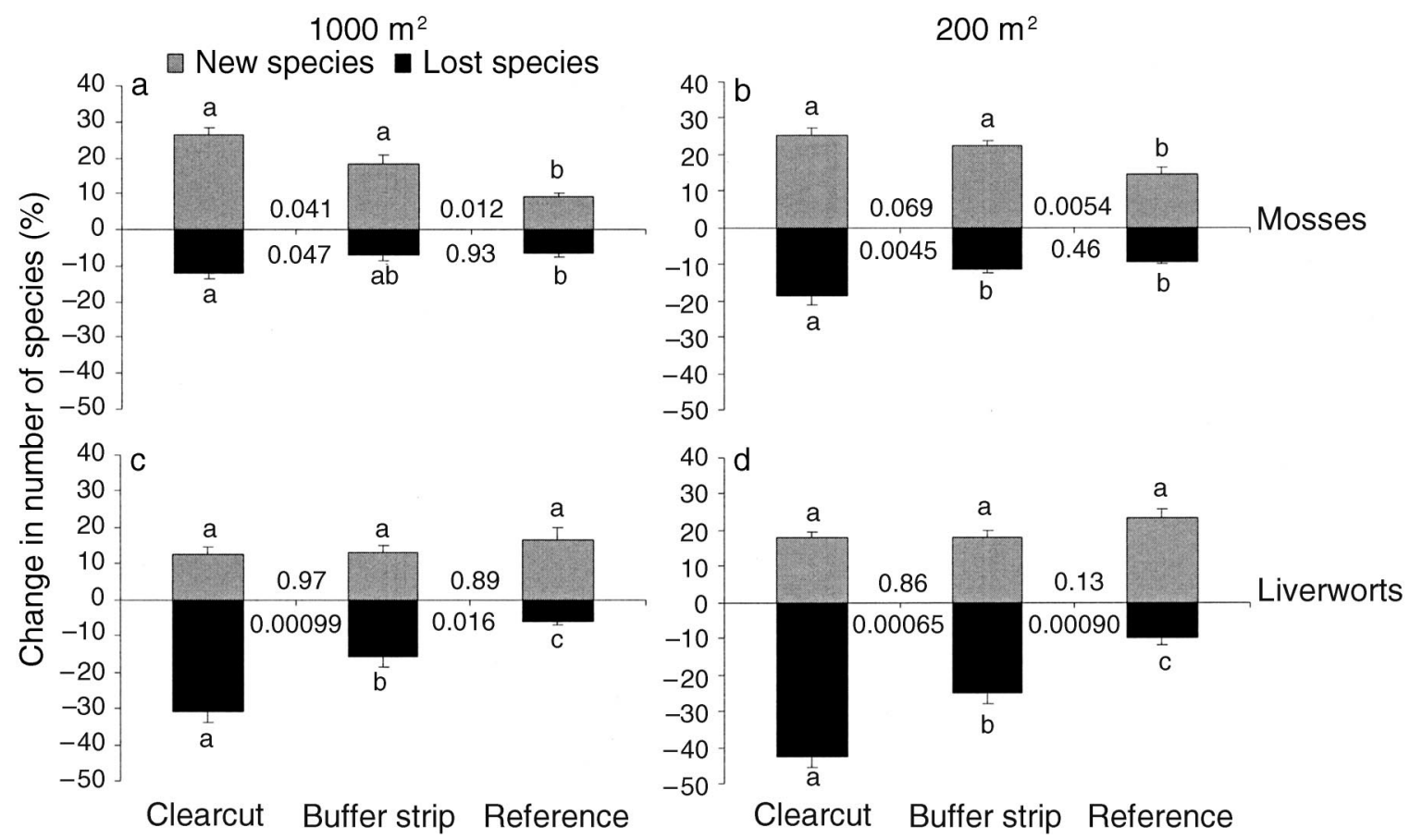

FIG. 6. Turnover of moss and liverwort species found in clearcuts $(N=15)$, buffer strips $(N=15)$, and reference sites $(N=10)$ between 1998 (pre-logging) and 2001 (post-logging) at two different scales: (a) mosses in 1000-m² plots, (b) mosses in $200-\mathrm{m}^{2}$ plots, (c) liverworts in $1000-\mathrm{m}^{2}$ plots, and (d) liverworts in $200-\mathrm{m}^{2}$ plots (error bars denote +1 SE). The letters denote significant differences $(P<0.025)$ between treatments, evaluated using Wilcoxon's signed-rank test (paired buffer strips vs. clearcuts) and Mann-Whitney $U$ test (comparisons with the references). $P$ values are given for the comparisons that include buffer strips.

along small streams will contribute to the "ecological memory" necessary for ecological resilience in the landscape (Bengtsson et al. 2003). The MRPP analysis, however, revealed that the change in species composition in the buffer strips after logging differed significantly from the situation in the references, and there were several species that exhibited a strong negative response in the buffer strips (Fig. 3). The correlation between the mean changes in frequency (the mean number of $200-\mathrm{m}^{2}$ segments per $1000-\mathrm{m}^{2}$ plot where the species was recorded) of the species in clearcuts and buffer strips indicated that the direction of response (positive or negative) for most species was similar in clearcuts and buffer strips, although the strength of the response was larger in the clearcuts (Fig. 3).

The substrate association was an important factor separating bryophyte species that were negatively affected, unaffected, or favored by the adjacent logging (Fig. 4). Many bryophytes on convex substrates (i.e., logs, stumps, tree bases, bark of deciduous trees, mesic ground, and boulders on land) were brown and yellow and obviously dead at the re-inventory, also in buffer strips with an intact tree cover, while bryophytes on concave surfaces (i.e., crevices, wet ground, moist ground, stream channel margins) were vigorous. Species on logs and tree bases were most negatively affected.
In Fennoscandia, the amount of woody debris has declined dramatically during the last century (Siitonen 2001). This has generated a situation in which many species of various organism groups depending on coarse logs and snags have decreased to the extent that they have become locally extinct and nationally redlisted (Siitonen 2001). Notably, most of the red-listed species recorded in this study are liverworts that grow on logs and other woody debris elevated from the forest floor (Appendix). They belong to the species that disappeared or decreased considerably in frequency in the buffer strips (Fig. 8). The interpretation of this is that bryophytes on convex surfaces in forests along streams are more dependent on a moist microclimate than their counterparts on concave surfaces that have access to moisture directly from the ground.

In general, the transformation of forest into a clearcut area or a buffer strip retains or improves ground water availability, making concave surfaces wetter $(\mathrm{Xu}$ et al. 2002), whereas convex surfaces become much drier because of increased exposure to wind and sun (cf. Brosofske et al. 1997). Many species on the forest floor and in crevices in wet sites were less sensitive to logging than species in moist and mesic riparian forests. This could at first seem counterintuitive, but many of these "wet" species also thrive well on open mires or road- and riverbanks and are not sensitive to high 


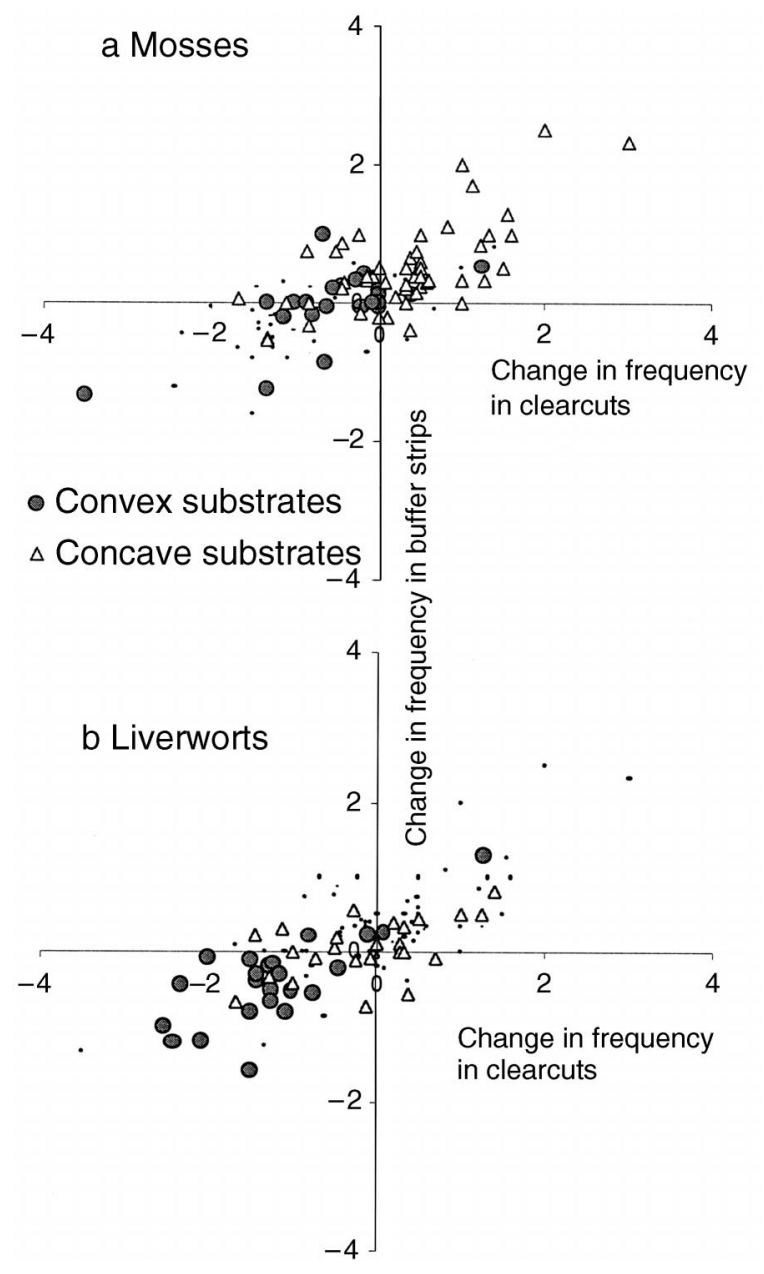

FIG. 7. The position along the axes of segment frequency changes following logging in clearcuts ( $x$-axis) and buffer strips ( $y$-axis) of (a) mosses and (b) liverworts grouped according to substrate form (concave vs. convex substrates). The figures include 121 species with their main substrate on convex or concave surfaces and occurring in at least two clearcuts and buffer strips in either 1998 or 2001. The segment frequency is the mean number of $200-\mathrm{m}^{2}$ plots occupied by the species per $1000-\mathrm{m}^{2}$ plot. Values along the axes represent the response of the species to logging, where a negative value denotes decreases in segment frequency of the species and a positive value denotes increases in segment frequency.

light levels (53\% of the concave species in buffer strips). The importance of a microclimate with moist air for bryophyte growth could be illustrated by the results from our previous study (Hylander et al. 2002) in buffer strips. Mosses in pots placed on boards that prevented the ground moisture from penetrating the pots grew better in wet than in mesic forests. This result indicated that the higher air humidity in the wet sites positively influenced the growth (Hylander et al. 2002).

Chen et al. (1999) stressed that variations in local climate can be used to compare the effects of different management practices. Changes in microclimatic properties in buffer strips after logging have indeed been demonstrated before (Brosofske et al. 1997). To our knowledge, however, this study is the first one that shows that changes in species composition of terrestrial organisms in buffer strips most likely are directly caused by an altered microclimate. In other types of forest clear-cut edges, it has been demonstrated that an altered microclimate has caused a change in species composition of the lichen (Kivistö and Kuusinen 2000) or vascular plant community (e.g., Matlack 1993, Young and Mitchell 1994). An observed edge effect in the composition of the vascular plant community can, however, also have been caused by other edge-related processes such as increased or decreased seed predation, herbivory, and deposition of seeds in the edge (Laurance and Yensen 1991, Gehlhausen et al. 2000). The close connection between microclimate and growth for poikilohydric organisms such as bryophytes and lichens makes them good indicators of microclimatic changes in the landscape, especially for changes in air moisture (cf. Busby et al. 1978, Gauslaa et al. 2001).

The different macrohabitat groups displayed different responses in the turnover of species after logging (Fig. 5). Forest species exhibited a clear decline, while

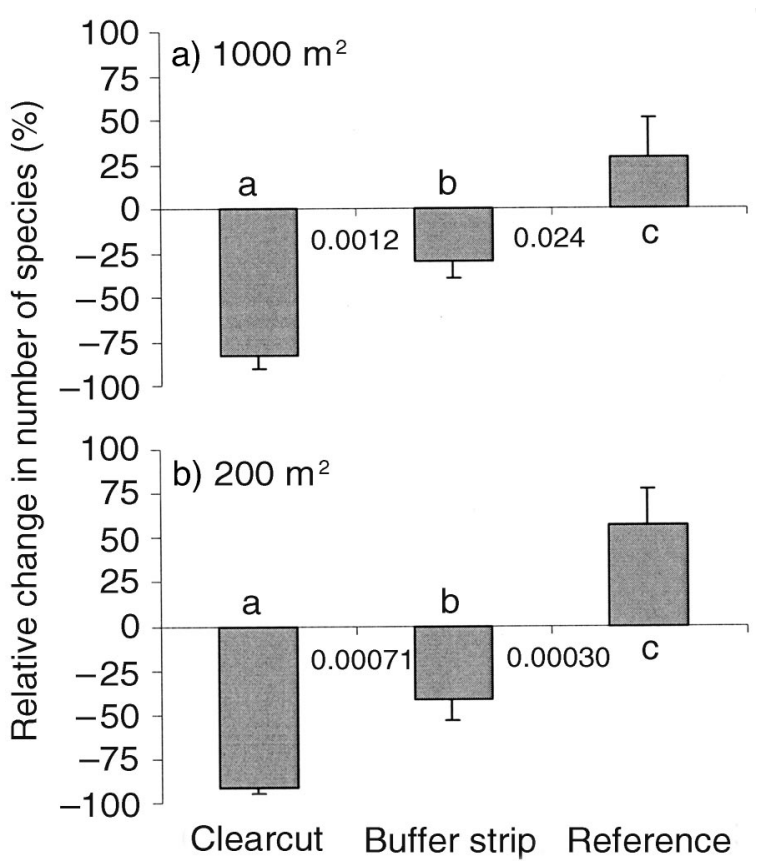

FIG. 8. Relative change in the number of red-listed bryophyte species between 1998 (pre-logging) and 2001 (postlogging) in clearcuts, buffer strips, and reference sites at two different plot sizes: (a) $1000-\mathrm{m}^{2}$ plots, and (b) $200-\mathrm{m}^{2}$ plots (error bars denote $+1 \mathrm{SE}$ ). The letters denote significant differences $(P<0.025)$ between treatments evaluated using Wilcoxon's signed-rank test (paired buffer strips vs. clearcuts) and Mann-Whitney $U$ test (comparisons with the references) with the relative change in number of species as the statistic. Only sites where red-listed species were found in 1998 were analyzed; hence, $N=11$ for clearcuts, $N=13$ for buffer strips, and $N=8$ for reference sites. $P$ values are given for the comparisons that include buffer strips. 
the response in the other groups either was very small or showed an increase in number of species per plot. This makes sense since species of open mires, rocky outcrops, or road- and riverbanks are adapted to a microclimate with sun and wind exposure. Many of the increasing species in the category road- and riverbanks are species mostly growing on exposed mineral soil (Appendix). This increase was larger in the clearcuts than in the buffer strips despite the larger increase of exposed mineral soil in the buffer strips due to windthrows. The reason for this difference was that these colonist species were favored by light and could grow on a larger variety of substrates in the clearcuts (e.g., on exposed humus, exposed peat, woody debris). None of these species are exotics, but are naturally found on disturbed soil in the boreal landscape. It is even possible that some of them were present in the spore bank already before logging (Jonsson 1993). However, many of these native species have probably increased in abundance and frequency during the last century along with increased areas of clearcuts and increased length of forest roads (cf. Hassel and Söderström 1998). These increasing and new species are opportunistic and are not expected to out-compete any other species. Instead, exposed mineral soil created by small-scale disturbance such as uprooting has been shown to be important for the maintenance of bryophyte forest-floor diversity in old-growth spruce forests (Jonsson and Esseen 1990). There are, however, few species in the boreal forest that are confined to exposed mineral soil in shaded conditions (with Schistostega pennata as one of few exceptions).

There was a clear difference between mosses and liverworts in their response to disturbance (cf. Fenton et al. 2003). The moss species had both a higher survival rate and a higher establishment rate after logging than did the liverworts (Fig. 6). Many liverworts in boreal riparian sites are associated with convex substrates such as logs, stumps, and tree bases (see Appendix). This cannot, however, be the full explanation for the difference, since liverworts on both convex and concave surfaces were significantly more sensitive than mosses growing there (also seen when Fig. 7a and b are compared). Most ecological literature on mosses and liverworts lumps them into one group: bryophytes. Since they are considered not to be a monophyletic group in most recent phylogenies (Goffinet 2000), it is important to highlight this difference in response to disturbance. Most liverworts are considered to be more drought sensitive than most mosses (Kurschner 1999), and it has been demonstrated that north-facing slopes have a more species-rich liverwort flora than southfacing slopes in Swedish boreal forests (Söderström 1981). The difference between mosses and liverworts in their response to disturbance deserves further attention.

It is largely unknown whether results from studies on mosses and liverworts can be extrapolated to other organism groups. However, their physiology and substrate specificity make them potential indicators of changing microclimatic conditions, especially concerning moisture (cf. Hylander et al. 2002). Most studies on terrestrial biota in buffer strips deal with birds. The general results from these studies suggest that narrow ( $<40 \mathrm{~m}$ on one side) buffer strips have a changed species composition (e.g., Darveau et al. 1995, Hagar 1999, Meiklejohn and Hughes 1999). In a study of the response of land snails to buffer strip retention, using the same plots as in this study, we found a decrease in snail abundance although the number of species per sample did not differ significantly from pre-logging conditions (Hylander et al. 2004). These responses differ from those observed for vascular plants, which were almost indifferent to edge effects in buffer strips the years after logging (Hibbs and Giordano 1996, Whitman and Hagan 2000, Hibbs and Bower 2001, Lamb et al. 2003). However, several studies on edge effects on vascular plants in non-riparian forests report distinct edge effects, at least in temperate forests (e.g., Matlack 1993, Gehlhausen et al. 2000). This indicates that there may be a difference in edge effect between riparian and non-riparian sites. Studies on lichens in boreal forests have shown significant edge effects in biomass (Esseen and Renhorn 1998), species composition (Kivistö and Kuusinen 2000), and species frequencies (Moen and Jonsson 2003). However, buffer strips were not studied.

We studied the bryophyte community in large plots compared to most other studies on bryophytes (e.g., Vellak and Paal 1999, Fenton et al. 2003, Økland et al. 2003, who used 0.04-1.25 $\mathrm{m}^{2}$ plots, but see Frisvoll and Prest $\varnothing 1997$ and Pharo and Beattie 1997, who used $100-1000 \mathrm{~m}^{2}$ plots). The change at the $200-\mathrm{m}^{2}$ scale was often more pronounced than at the $1000-\mathrm{m}^{2}$ scale (Figs. 4, 6, and 8). Had we used smaller plots, e.g., the common $1-\mathrm{m}^{2}$ plot size, we would have found decreases for more of the abundant species in the clearcuts, since the overall cover of bryophytes declined so sharply. On the other hand, we would have missed most of the infrequent species (or got very small samples of them) unless we had analyzed large numbers of plots. It is interesting to note that mapping every subpopulation of the red-listed species only added slightly more accuracy than just presence/absence data for $200 \mathrm{~m}^{2}$ (see Methods section). This confirms that the chosen scale was relevant for the more rare species, but too coarse to make any statements on changes in population sizes of the most abundant species. If the focus is on species survival at the stand scale, large sampling plots should be used. We think that there are good conditions for future survival at the stand scale if a species that occurred in every segment $\left(200 \mathrm{~m}^{2}\right)$ before logging also can be found there after logging, even if it decreased in abundance (assuming that the years after the logging event represent the bottleneck successional stage). 


\section{Management implications}

Forests along small streams have more bryophyte species than non-riparian sites (Dynesius 2001). Wisely managed, this habitat is potentially important for bryophyte conservation on a landscape scale (i.e., 1-100 $\mathrm{km}^{2}$ ). If the main objective of the retention of buffer strips is not to protect terrestrial species sensitive to clear-cutting, the result from this study that half of the 200- $\mathrm{m}^{2}$ segment records of red-listed species survived the first 2.5 years after logging could be seen as a conservation bonus (compared to the situation in the clearcuts where most of the red-listed species disappeared). However, in order to function better as highquality habitat and refugia for such species, riparian forests need to be protected from high windthrow frequencies and strong edge effects (some low number of windthrows would, however, only be valuable). This can be achieved through wider buffer strips, smaller clearcuts in the direction of the most likely windstorms, and through planning of the logging to avoid clearcuts on both sides of the stream during the same period. All other things being equal, it is likely that wider strips need to be retained on level ground (compared to marked valleys), south-facing clear-cut edges (compared to north-facing edges), and at sites with a high canopy if the same microclimate is going to be maintained (cf. Murica 1995, Dignan and Bren 2003). Our results imply that more care should be taken at sites with many convex substrates such as boulders and logs, not least on moist and mesic sites, in order to protect the most sensitive species.

From a bryophyte conservation perspective, it is better to adjust the width of the buffer strip to known or potential values in the riparian forests than to have a fixed width of narrow buffers throughout the landscape. A variation of width and more emphasis on the protection of core area (with less edge effect) than on buffer width have also been shown to be important for birds in riparian corridors (Groom and Grubb 2002). Moen and Jonsson (2003) found that the cover of epiphytic liverworts on forest islands in a vast mire landscape in northern Sweden experienced edge effects of $\sim 50 \mathrm{~m}$. If this is a general pattern, it implies that a buffer of $50 \mathrm{~m}$ should be retained in addition to the area of concern for conservation purposes if negative edge effects should be avoided. However, the results on species' responses to microclimatic changes depending on substrate form might be possible to extrapolate to forms in the landscape. We thus hypothesize that the edge effects in concave parts of the landscape (such as valleys with streams) are less severe than in convex parts (such as the islands studied in the cited study), which might imply that buffer strips narrower than $50 \mathrm{~m}$ could be effective.

\section{ACKNOWLEDGMENTS}

We thank SCA for providing us with field sites and for logging them according to our instructions. We also thank L.
Hedenäs and K. Damsholt for checking the identification of difficult specimens, and J. Blom, T. Göthner, S. Hylander, and J. Temnerud for assisting with the fieldwork. The study was supported by grants from The Swedish Research Council for Environment, Agricultural Sciences and Spatial Planning (to C. Nilsson).

\section{Literature Cited}

Ahti, T., L. Hämet-Ahti, and J. Jalas. 1968. Vegetation zones and their sections in northwestern Europe. Annales Botanici Fennici 5:169-211.

Anonymous. 1999. Väder och Vatten 1999. Swedish Meteorological and Hydrological Institute (SMHI), Norrköping, Sweden.

Anonymous. 2000. Väder och Vatten 2000. Swedish Meteorological and Hydrological Institute (SMHI), Norrköping, Sweden.

Anonymous. 2001. Väder och Vatten 2001. Swedish Meteorological and Hydrological Institute (SMHI), Norrköping, Sweden.

Aronsson, M., T. Hallingbäck, and J.-E. Mattsson, editors. 1995. Rödlistade växter i Sverige 1995 [Swedish red data book of plants 1995]. ArtDatabanken, Uppsala, Sweden.

Bengtsson, J., P. Angelstam, T. Elmqvist, U. Emanuelsson, C. Folke, M. Ihse, F. Moberg, and M. Nyström. 2003. Reserves, resilience and dynamic landscapes. Ambio 32:389396.

Berglund, H., and B. G. Jonsson. 2001. Predictability of plant and fungal species richness of old-growth boreal forest islands. Journal of Vegetation Science 12:857-866.

Blinn, C. R., and M. A. Kilgore. 2001. Riparian management practices - a summary of state guidelines. Journal of Forestry 99:11-17.

Brosofske, K. D., J. Q. Chen, R. J. Naiman, and J. F. Franklin. 1997. Harvesting effects on microclimatic gradients from small streams to uplands in western Washington. Ecological Applications 7:1188-1200.

Burton, P. J., C. Messier, D. W. Smith, and W. L. Adamowicz. 2003. Towards sustainable management of the boreal forest. NRC Research Press, Ottawa, Canada.

Busby, J. R., L. C. Bliss, and C. D. Hamilton. 1978. Microclimate control of growth rates and habitats of the boreal forest mosses Tomentlypnum nitens and Hylocomium splendens. Ecological Monographs 48:95-110.

Castelle, A. J., A. W. Johnson, and C. Conolly. 1994. Wetland and stream buffer size requirements-a review. Journal of Environmental Quality 23:878-882.

Chen, J. Q., S. C. Saunders, T. R. Crow, R. J. Naiman, K. D. Brosofske, G. D. Mroz, B. L. Brookshire, and J. F. Franklin. 1999. Microclimate in forest ecosystem and landscape ecology: variations in local climate can be used to monitor and compare the effects of different management regimes. BioScience 49:288-297.

Cockle, K. L., and J. S. Richardson. 2003. Do riparian buffer strips mitigate the impacts of clearcutting on small mammals? Biological Conservation 113:113-140.

Darveau, M., P. Beauchesne, L. Belanger, J. Huot, and P. Larue. 1995. Riparian forest strips as habitat for breeding birds in boreal forest. Journal of Wildlife Management 59: 67-78.

DeLuca, T. H., O. Zackrisson, M.-C. Nilsson, and A. Sellstedt. 2002. Quantifying nitrogen-fixation in feather moss carpets of boreal forests. Nature 419:917-920.

Dignan, P., and L. Bren. 2003. Modeling light penetration edge effects for stream buffer design in mountain ash forest in southeastern Australia. Forest Ecology and Management 179:95-106

Dynesius, M. 2001. Spatial and evolutionary aspects of species diversity, species traits, and human impact with examples from boreal riparian and forest plant communities. 
Dissertation. Department of Ecology and Environmental Science, Umeå University, Umeå, Sweden.

Esseen, P.-A., B. Ehnström, L. Ericson, and K. Sjöberg. 1992. Boreal forests: the focal habitats of Fennoscandia. Pages 252-325 in L. Hansson, editor. Ecological principles of nature conservation. Elsevier, London, UK.

Esseen, P. A., and K. E. Renhorn. 1998. Edge effects on an epiphytic lichen in fragmented forests. Conservation $\mathrm{Bi}$ ology 12:1307-1317.

Fenton, N. J., K. A. Frego, and M. R. Sims. 2003. Changes in forest floor bryophyte (moss and liverwort) communities four years after forest harvest. Canadian Journal of Botany 81:714-731.

Fredén, C., editor. 1994. National atlas of Sweden: geology. SNA Publishing, Stockholm, Sweden.

Fries, C., O. Johansson, B. Pettersson, and P. Simonsson. 1997. Silvicultural models to maintain and restore natural stand structures in Swedish boreal forests. Forest Ecology and Management 94:89-103.

Frisvoll, A. A., and T. Prestø. 1997. Spruce forest bryophytes in central Norway and their relationship to environmental factors including modern forestry. Ecography 20:3-18.

Gärdenfors, U., editor. 2000. Rödlistade arter i Sverige 2000 [The 2000 red list of Swedish species]. ArtDatabanken, Uppsala, Sweden.

Gauslaa, Y., M. Ohlson, and K. A. Solhaug. 2001. Aspectdependent high-irradiance damage in two transplanted foliose forest lichens, Lobaria pulmonaria and Parmelia sulcata. Canadian Journal of Forest Research 31:1639-1649.

Gehlhausen, S. M., M. W. Schwartz, and C. K. Augspurger. 2000. Vegetation and microclimatic edge effects in two mixed-mesophytic forest fragments. Plant Ecology 147:2135.

Goffinet, B. 2000. Origin and phylogenetic relationships of bryophytes. Pages 124-149 in A. J. Shaw and B. Goffinet, editors. Bryophyte biology. Cambridge University Press, Cambridge, UK.

Gomi, T., R. C. Sidle, and J. S. Richardson. 2002. Understanding processes and downstream linkages of headwater systems. BioScience 52:905-916.

Granström, A. 2001. Fire management for biodiversity in the European boreal forest. Scandinavian Journal of Forest Research Supplement 3:62-69.

Groom, J. D., and T. C. Grubb. 2002. Bird species associated with riparian woodland in fragmented, temperate-deciduous forest. Conservation Biology 16:832-836.

Hagar, J. C. 1999. Influence of riparian buffer width on bird assemblages in Western Oregon. Journal of Wildlife Management 63:484-496.

Hägglund, B., and J.-E. Lundmark. 1981. Handledning i bonitering med Skogshögskolans boniteringssystem. Skogsstyrelsen, Jönköping, Sweden.

Hannerz, M., and B. Hånell. 1997. Effects on the flora in Norway spruce forests following clearcutting and shelterwood cutting. Forest Ecology and Management 90:29-49.

Hansen, A. J., T. A. Spies, F. J. Swanson, and J. F. Ohmann. 1991. Conserving biodiversity in managed forests: lessons from natural forests. BioScience 41:382-392.

Hassel, K., and L. Söderström. 1998. The presence of Pogonatum dentatum (Brid.) Brid. in roadside diaspore banks in Sweden. Lindbergia 23:113-118.

Hazell, P., and L. Gustafsson. 1999. Retention of trees at final harvest: evaluation of a conservation technique using epiphytic bryophyte and lichen transplants. Biological Conservation 90:133-142.

Hibbs, D. E., and A. L. Bower. 2001. Riparian forests in the Oregon Coast Range. Forest Ecology and Management 154: 201-213.

Hibbs, D. E., and P. A. Giordano. 1996. Vegetation characteristics of alder-dominated riparian buffer strips in the Oregon Coast Range. Northwest Science 70:213-222.
Hörnberg, G., O. Zackrisson, U. Segerström, B. W. Svensson, M. Ohlson, and R. H. W. Bradshaw. 1998. Boreal swamp forests. BioScience 48:795-802.

Hylander, K., B. G. Jonsson, and C. Nilsson. 2002. Evaluating buffer strips along boreal streams using bryophytes as indicators. Ecological Applications 12:797-806.

Hylander, K., C. Nilsson, and T. Göthner. 2004. Effects of buffer strip retention and clearcutting on land snails in boreal riparian forests. Conservation Biology 18:1052-1062.

Jalonen, J., and I. Vanha-Majamaa. 2001. Immediate effects of four different felling methods on mature boreal spruce forest understory vegetation in southern Finland. Forest Ecology and Management 146:25-34.

Jonsson, B. G. 1993. The bryophyte diaspore bank and its role after small-scale disturbance in a boreal forest. Journal of Vegetation Science 4:819-826.

Jonsson, B. G., and P. A. Esseen. 1990. Treefall disturbance maintains high bryophyte diversity in a boreal spruce forest. Journal of Ecology 78:924-936.

Jönsson, K. I. 2003. Population density and species composition of moss-living tardigrades in a boreo-nemoral forest. Ecography 26:356-364.

Kivistö, L., and M. Kuusinen. 2000. Edge effects on the epiphytic lichen flora of Picea abies in middle boreal Finland. Lichenologist 32:387-398.

Kohm, K. A., and J. F. Franklin. 1997. Creating a forestry for the 21st century. Island Press, Washington, D.C., USA.

Kurschner, H. 1999. Life strategies of epiphytic bryophytes in Mediterranean Pinus woodlands and Platanus orientalis alluvial forests of Turkey. Cryptogamie Bryologie 20:1733.

Kuuluvainen, T. 2002. Natural variability of forests as a reference for restoring and managing biological diversity in boreal Fennoscandia. Silva Fennica 36:97-125.

Lamb, E. G., A. U. Mallik, and R. W. Mackereth. 2003. The early impact of adjacent clearcutting and forest fire on riparian zone vegetation in northwestern Ontario. Forest Ecology and Management 177:529-538.

Larsson, S., and K. Danell. 2001. Science and the management of boreal forest biodiversity. Scandinavian Journal of Forest Research Supplement 3:5-9.

Laurance, W. F., and E. Yensen. 1991. Predicting the impacts of edge effects in fragmented habitats. Biological Conservation 55:77-92.

Macdonald, E., C. J. Burgess, G. J. Scrimgeour, S. Boutin, S. Reedyk, and B. Kotak. 2004. Should riparian buffers be part of forest management based on emulation of natural disturbance? Forest Ecology and Management 187:185196.

Matlack, G. R. 1993. Microenvironment variation within and among forest edge sites in the eastern United-States. Biological Conservation 66:185-194.

McCune, B., and M. J. Mefford. 1999. PC-ORD. Multivariate analysis of ecological data, Version 4. MjM Software Design, Gleneden Beach, Oregon, USA.

Meiklejohn, B. A., and J. W. Hughes. 1999. Bird communities in riparian buffer strips of industrial forests. American Midland Naturalist 141:172-184.

Meleason, M. A., S. V. Gregory, and J. P. Bolte. 2003. Implications of riparian management strategies on wood in streams of the Pacific Northwest. Ecological Applications 13:1212-1221.

Moen, J., and B. G. Jonsson. 2003. Edge effects on liverworts and lichens in forest patches in a mosaic of boreal forest and wetland. Conservation Biology 17:380-388.

Moore, R. D., and J. S. Richardson. 2003. Progress towards understanding the structure, function, and ecological significance of small stream channels and their riparian zones. Canadian Journal of Forest Research 33:1349-1351. 
Murica, C. 1995. Edge effects in fragmented forests-implications for conservation. Trends in Ecology and Evolution 10:58-62.

Niemelä, J. 1999. Management in relation to disturbance in the boreal forest. Forest Ecology and Management 115: 127-134.

Niemelä, J., S. Larsson, and D. Simberloff. 2001. Concluding remarks: finding ways to integrate timber production and biodiversity in Fennoscandian forestry. Scandinavian Journal of Forest Research Supplement 3:119-123.

Nilsson, N.-E., editor. 1990. The national atlas of Sweden: the forests. National Board of Forestry, Jönköping, Sweden.

Norušis, M. J. 1999. SPSS for Windows. Version 10.0. SPSS, Chicago, Illinois, USA.

Økland, T., K. Rydgren, R. H. Økland, K. O. Storaunet, and J. Rolstad. 2003. Variation in environmental conditions, understorey species number, abundance and composition among natural and managed Picea abies forest stands. Forest Ecology and Management 177:17-37.

Pearson, S. F., and D. A. Manuwal. 2001. Breeding bird response to riparian buffer width in managed Pacific Northwest Douglas-fir forests. Ecological Applications 11:840853.

Pharo, E. J., and A. J. Beattie. 1997. Bryophyte and lichen diversity: a comparative study. Australian Journal of Ecology 22:151-162.

Proctor, M. C. F. 1990. The physiological basis of bryophyte production. Botanical Journal of the Linnean Society 104: 61-77.

Raab, B., and H. Vedin, editors. 1995. The national atlas of Sweden: climate, lakes and rivers. SNA Publisher, Stockholm, Sweden.

Schofield, W. B. 1985. Introduction to bryology. Blackburn Press, Caldwell, New Jersey, USA.

Siitonen, J. 2001. Forest management, coarse woody debris and saproxylic organisms: Fennoscandian boreal forests as an example. Ecological Bulletins 49:11-41.
Simberloff, D. 1999. The role of science in the preservation of forest biodiversity. Forest Ecology and Management 115:101-111.

Söderström, L. 1981. Distribution of bryophytes in spruce forests on hill slopes in central Sweden. Wahlenbergia 7: $141-153$.

Söderström, L., and L. Hedenäs. 1998. Checklista över Sveriges mossor-1998 [A checklist to the bryophytes of Sweden]. Myrinia 8:58-90.

Söderström, L., H. Weibull, and K. Damsholt. 2000. A new species of Lophozia (subgen. Protolophozia) from Fennoscandia. Lindbergia 25:3-5.

Swanson, F. J., and J. F. Franklin. 1992. New forestry principles from ecosystem analysis of pacific-northwest forests. Ecological Applications 2:262-274.

Vanha-Majamaa, I., and J. Jalonen. 2001. Green tree retention in Fennoscandian forestry. Scandinavian Journal of Forest Research Supplement 3:79-90.

Vellak, K., and J. Paal. 1999. Diversity of bryophyte vegetation in some forest types in Estonia: a comparison of old unmanaged and managed forests. Biodiversity and Conservation 8:1595-1620.

Whitman, A. A., and J. M. Hagan. 2000. Herbaceous plant communities in upland and riparian forest remnants in western Maine. Mosaic Science Notes 1-8. Management Center for Conservation Sciences, Brunswick, Maine, USA.

Xu, Y. J., J. A. Burger, W. M. Aust, S. C. Patterson, M. Miwa, and D. P. Preston. 2002. Changes in surface water table depth and soil physical properties after harvest and establishment of loblolly pine (Pinus taeda L.) in Atlantic coastal plain wetlands of South Carolina. Soil and Tillage Research 63:109-121.

Young, A., and N. Mitchell. 1994. Microclimate and vegetation edge effects in a fragmented Podocarp-broadleaf forest in New Zealand. Biological Conservation 67:63-72.

Zimmerman, G. M., H. Goetz, and P. W. Mielke. 1985. Use of an improved statistical method for group comparisons to study effects of prairie fire. Ecology 66:606-611.

\section{APPENDIX}

A table listing the number of records and mean change in frequency of each bryophyte species in the $1000-\mathrm{m}^{2}$ plots before (1998) and after (2001) logging is available in ESA's Electronic Data Archive: Ecological Archives A015-017-A1. 